\title{
Aspergillus sp. For Indigosol Blue and Remazol Brilliant Blue $\mathbf{R}$ Decolorization
}

\author{
Fitria Ayudi Ulfimaturahmah ${ }^{1}$, Ratna Stia Dewi ${ }^{2}$, Ajeng Arum Sari ${ }^{3}$ \\ ${ }^{1,2}$ Fakultas Biologi, Universitas Jenderal Soedirman \\ Jalan dr Suparno 63 Purwokerto 53122 \\ ${ }^{3}$ Pusat Penelitian Kimia, LIPI \\ email: ratna.dewi0509@unsoed.ac.id
}

\begin{abstract}
Rekam Jejak Artikel:
Diterima : 28/08/2019

Disetujui : $15 / 12 / 2020$

Abstract

Synthetic dyes are artificial dyes manufactured by Industry and commonly used for the textile industry. These dyes had potentially caused an environmental problem. Many types of dyes are recalcitrant and have toxic properties for living organisms. It can be removed by decolorization method, especially a biological decolorization by fungi. Fungi were chosen due to the ability to degrade toxic components. Aspergillus sp. is the fungi which commonly used for dye decolorization. It might be caused that Aspergillus sp. is one type of fungi lived in the textile waste and expected not to die in the dye decolorization treatment. The purpose of this research was to investigate the ability of the mycelia pellets of Aspergillus sp to decolorized Indigosol Blue dye and Remazol Brilliant Blue R (RBBR) dye. This research showed that mycelial pellets of Aspergillus sp. had high activity of decolorization of Indigosol Blue dye up to $85.37 \%$ and RBBR dye up to $80.21 \%$ and caused low $\mathrm{pH}$ value after 24 hour incubation time compared to the control solution.

Keywords: Aspergillus sp., decolorization, $p H$.
\end{abstract}

\section{INTRODUCTION}

Synthetic dyes are artificial dyes manufactured by the manufacturing industry. These dyes are commonly used for the textile industry. It also potentially caused an environmental problem. The dye pollutant in water releases products that are toxic, mutagenic, and carcinogenic to the living organisms so that it creates a hazardous problem (Bassyouni et al., 2017). The example of synthetic dyes is Remazol Brilliant Blue R (RBBR) and Indigosol Blue. Both of them are anthraquinone dyes and difficult to degraded. Dye compounds can be decolorized by physical and chemical methods, however, it required high costs and produced dangerous compounds (Awaluddin et al. 2001). The biological method used as an alternative method because it is cheap and environmentally friendly (Dewi \& Lestari 2010).
Aspergillus sp. is one type of fungi found in textile waste and can be used as a dye decolorization agent. Hefnawy et al. (2017) reported the fungi decolorization of dye could be achieved by treating with Aspergillus flavus and Aspergillus niger. This research used isolates of Aspergillus sp. 2 as collection from Dewi et al. (2018a,b, 2019). They reported that Aspergillus sp. 2 has characteristic as yellow-green colony color, white mycelium color, and also has a vesicle, metullae, phialides, and foot cells. The fungal degradation products did not cause any toxicity in plants. Aspergillus is known to be very effective in decolorizing various types of dyes even compared to other microfungi. Aspergillus sp. was very effective in the removal of biochemical oxygen demand (BOD), chemical oxygen demand (COD), total dissolved solids (TDS), total suspended solids (TSS), and electrical conductance (EC). Dewi \& 
Lestari (2010) reported that genus Aspergillus sp. is fungi which has a better ability than Fusarium sp. to decolorize handmade batik wastewater.

The problem of this research was how the ability of mycelia pellets of Aspergillus sp. to decolorized the dyes. The purpose of this research was to investigate the ability of the mycelia pellets of Aspergillus sp. on dyes decolorization.

\section{MATERIAL AND METHODS}

The material used in this research was isolate of Aspergillus sp. (Dewi et al., 2018a,b). The tools used in this research are rotary shaker, spectrophotometry, $\mathrm{pH}$ meter, sterile blender, laminar airflow (LAF), and autoclave.

\section{Test solution preparation}

The test solution also prepared and consisted of $90 \mathrm{~mL}$ Malt Extract (ME) medium and $10 \mathrm{~mL}$ dye solution (Zhang \& Yu, 2000). The test solution was contained as $100 \mathrm{ppm}$ dye solution.

\section{Adsorbent preparation (Zhang \&Yu, 2000).}

The fungi cultures are inoculated on $\mathrm{ME}$ medium and cultivated on the rotary shake bath 100 rpm for five days. Then, mycelia pellets were homogenized aseptically by using the sterilized blender. Five millilitres inoculum continued to inoculate on ME medium. Then, Erlenmeyer flask was incubated on rotary shaker $100 \mathrm{rpm}$ for four days. Mycelia pellets were formed, harvested, and used as $5 \mathrm{~g}$ wet pellets in $100 \mathrm{~mL}$ test solution.

\section{Treatments preparation.}

The sampling was carried out for 24 hours. Then, the samples were analyzed for dye decolorization test and $\mathrm{pH}$ measurement.

\section{Dye decolorization}

The samples were analyzed by UV-vis spectrophotometry. The percentage of decolorization was analyzed by the formula:

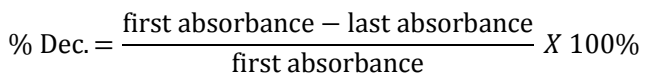

Note.

Dec. $=$ decolorization

$\mathrm{pH}$ measurement

The samples were taken from the Erlenmeyer flask. The $\mathrm{pH}$ was measured on the control solution and the dyes solution after 24 hour incubation time.

\section{RESULT AND DISCUSSION}

The decolorization assay has been carried out on the RBBR dye and Indigosol Blue dye by using mycelial pellets of Aspergillus sp. The initial dye concentration on the test solution was 100 ppm. The decolorization percentage of Indigosol Blue dye and RBBR dye was shown in Figure 1.

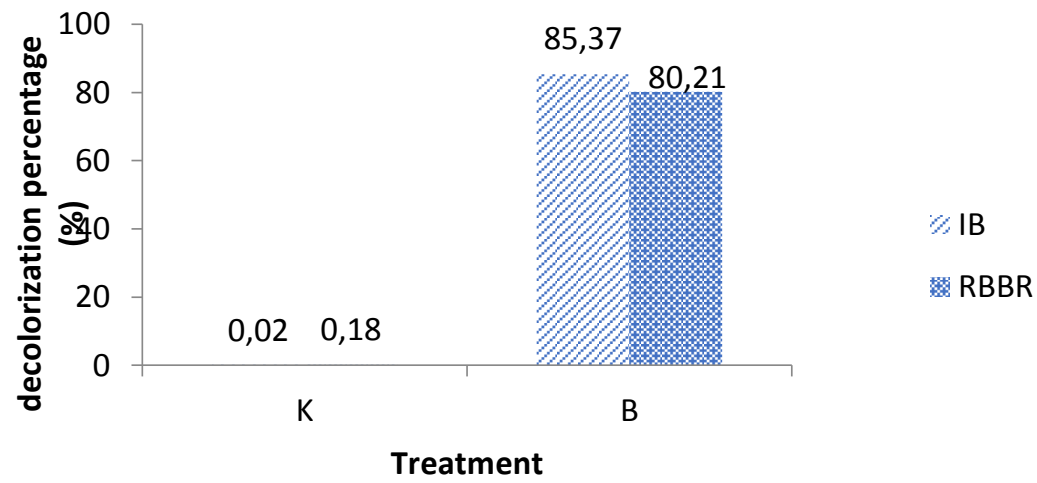

Figure 1. Histogram of decolorization percentage of Indigosol Blue dye and RBBR dye using Aspergillus sp. mycelia Note: pellets.

$\mathrm{K}=$ Control

$\mathrm{B}=$ mycelia pellets 
The result showed that the decolorization percentage of adsorbent $\mathrm{B}$ on Indigosol Blue dye was $85.37 \%$, while RBBR dye was $80.21 \%$. Then, the control solution on Indigosol Blue dye has $0.02 \%$ and RBBR has $0.18 \%$. This result was indicted that the mycelial pellets of Aspergillus sp. have the ability to decolorized the dyes. Aspergillus sp. used in this research has morphological characters as dark green colony color, reverse colony color is yellowish to brown, has spores, powdery surface, concentric distribution, and microfungi. According to Dewi et al. (2018a,b), Aspergillus sp. has characteristics as yellow-green colony color, white mycelium color, spore diameter as $50 \mu \mathrm{m}$, and also has vesicle, metullae, phialides, and foot cells. This fungus was a collection from Dewi et al. (2018a,b) as indigenous fungi isolated from dye effluent. The type of indigenous fungi was used as a dye decolorization agent. Beside expected to have resistance to conditions below normal, it also can degrade dyes. Singh et al. (2018) also reported that Aspergillus sp. isolated from the sludge of textile industry can grow in the presence of dye and was effective in removing dye. The growth of indigenous isolate from sludge textile was efficient to decolorized the dye solutions at higher concentrations. Przystas et al. (2018) also reported that decolorization effectiveness depended on the strain used in the process. It was demonstrated that strains isolated from polluted sites had a greater decolorization potential than others.

The $\mathrm{pH}$ was measured on the control solution and Indigosol Blue dye and RBBR dye solution with mycelia pellets of Aspergillus sp. The $\mathrm{pH}$ of both of the dyes has a lower value than the control solution (Figure 2).

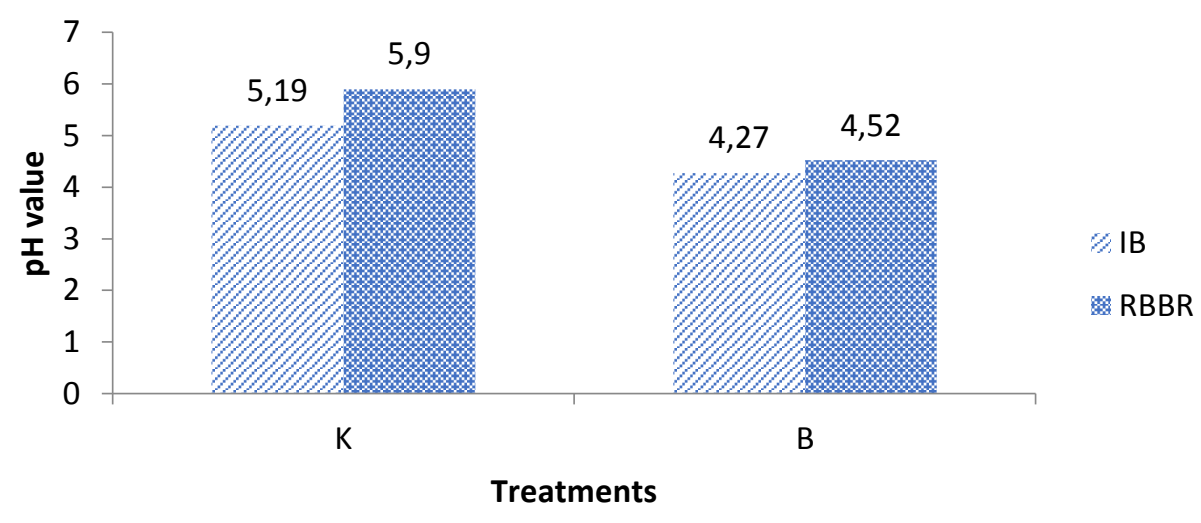

Note:

$\mathrm{K}=$ Control

$\mathrm{B}=$ mycelia pellets

The result showed that the $\mathrm{pH}$ of mycelia pellets of Aspergillus sp. on Indigosol Blue dye was 4.27, while RBBR dye was 4.52. Then, the $\mathrm{pH}$ of control on Indigosol Blue dye was 5.19, while RBBR dye was 5.9. It means that the mycelia pellets of Aspergillus sp. had the ability to decolorize the dye indicated by decreasing $\mathrm{pH}$. This is similar to Hadianto (2000), in the decreasing of acidic $\mathrm{pH}$ conditions, the absorbance value decreases so that the percentage of decolorization is greater. Kunjadia et al. (2016) reported that the effect of initial $\mathrm{pH}$ on dye decolorization by fungi varied depending on the type of the dye. Yucel (2018) reported the dye decolorization rate increases up to almost $70 \%$ in the $\mathrm{pH}$ range 3-4 and decreased with the increasing $\mathrm{pH}$ value. 
Based on the result, it can be known that mycelia pellets of Aspergillus sp. has the ability to decolorized the dye, which indicated by decreasing absorbance value. In addition, mycelial pellets of Aspergillus sp. showed the decreasing $\mathrm{pH}$ to an acidic condition which correspondingly to the decreasing of absorbance value. The result showed that Indigosol Blue dye has a higher decolorization percentage compared to RBBR dye. Correspondingly, the $\mathrm{pH}$ of Indigosol dye after decolorizattion process was lower than RBBR dye. It might be indicated that the Indigosol Blue dye was easier to decolorized than RBBR dye. RBBR dye has a chemical formula $\mathrm{C}_{22} \mathrm{H}_{16} \mathrm{~N}_{2} \mathrm{Na}_{2} \mathrm{O}_{11} \mathrm{~S}_{3}$ (Ahmad et al., 2011). Steingruber (2004) also reported that the chemical formula of Indigosol dye is $\mathrm{C}_{16} \mathrm{H}_{10} \mathrm{~N}_{2} \mathrm{O}_{2}$. It is indicated that Indigosol Blue dye had a total of 16 Carbon, 10 Hydrogen, and 2 Oxygen. Besides, RBBR had a total of 22 Carbon, 16 Hydrogen, and 11 Oxygen.
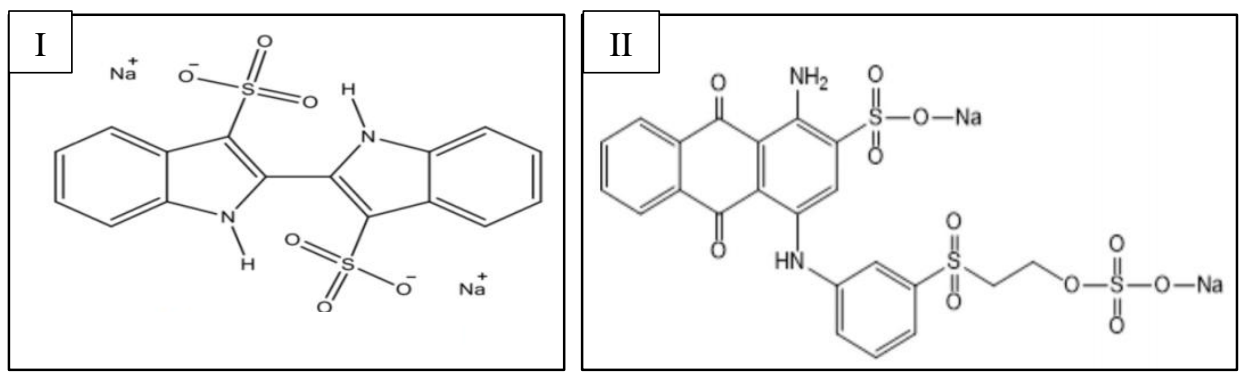

Figure 3. (I) The chemical chain of Indigosol blue dyes (Aryanti et al., 2017); (II) The chemical chain of Remazol Brilliant Blue R dye (Torgut et al., 2017).

Indigosol dye is a reactive synthetic dye commonly used as a fabric dye and widely used to produce light and bright colors (Aryanti et al., 2017). Indigosol Blue is one of the anthraquinone synthetic dyes (Herfiani et al., 2017). RBBR (Figure 3) is an anthraquinone dye which is one of the chromophoric groups (Rahmat et al., 2016). RBBR was widely used in the textile industry due to its favourable characteristics such as low energy consumption, simple application techniques and not readily biodegradable (Ahmad \& Alrozi, 2011).

\section{CONCLUSION}

Aspergillus sp. has the ability to decolorize the Indigosol Blue dye up to $85.37 \%$ and RBBR dye up to $80.21 \%$. It was indicated by high decolorization percentage and lower $\mathrm{pH}$ value after 24 hours incubation compared to the control solution. Then, the result also showed that Indigosol Blue dye was easier to decolorized than RBBR dye.

\section{REFERENCES}

Ahmad, M. A., \& Alrozi, R., 2011. Optimization of Rambutan Peel Based Activated Carbon Preparation Conditions for Remazol Brilliant Blue R Removal. Chemical Engineering Journal, 168(1) : 280-5.

Ahmad, M. A., Yun, E. T. C., Abustan, I., Ahmad, N., \& Sulaiman, S. K., 2011. Optimization of Preparation Conditions for Corn Cob Based Activated Carbons for the Removal of Remazol Brilliant Blue $\mathrm{R}$ dye. International Journal of Engineering \& Technology, 11(1) : 216-221.

Aryanti, N., Sandria, F. K. I., Putriadi, R. H., \& Wardhani, D. H., 2017. Evaluation of Micellar-Enhanced Ultrafiltration (MEUF) Membrane for Dye Removal of Synthetic Remazol Dye Wastewater. Engineering Journal, 21(3) : 23-35.

Awaluddin, R., Darah, S., Ibrahim, C. D. \& Uyub, A. M., 2001. Decolorization of Commercially Available Synthetic Dyes by The White Rot Fungus Phanerochaete chrysosporium ME 446 (ATCC 34541). Kuala Lumpur, Proceedings of NSF Workshop.

Bassyouni, D. G., Hamad, H. A., El-Ashtoukhy, ES. Z., Amin, N. K., and Abd-El Latif, M. M., 2017. Comparative performance of 
anodic oxidation and electrocoagulation as clean processes for electrocatalytic degradation of diazo dye Acid Brown 14 in aqueous medium. Journal of Hazardous Material, 335 : 178-187.

Dewi, R. S., \& Lestari, S., 2010. Dekolorisasi Limbah Batik Tulis Menggunakan Jamur Indigenous Hasil Isolasi pada

Konsentrasi Limbah yang Berbeda. Molekul, $5(2): 75-82$.

Dewi, R. S., Kasiamdari, R. S., Martani, E. \& Purwestry, Y. A., 2018a. Bioremediation of Indiosol Blue-04B Batik effluent by Indienous Fungal Isolates, Aspergillus spp. Omni Akuatika, 14(2) : 11-20.

Dewi, R. S., Kasiamdari, R. S., Martani, E. \& Purwestry, Y. A., 2018b. Decolorization and detoxification of batik dye effluent containing Indigosol Blue-04B using fungi isolated from contaminated dye effluent.Indonesian Journal of Biotechnology, 23(2) : 54-60.

Dewi, R. S., Kasiamdari, R. S., Martani, E. \& Purwestry, Y. A., 2019. Optimization of The Conditions for The Decolorization of Batik Wastewater by Aspergillus sp. 3. AIP Conference Proceedings. Hlm. 1-9. [online] https://aip.scitation.org/doi/abs/10.1063/1. 5097505 [Diakses 28 Agustus 2019].

Hadianto A. D., 2000. Pengaruh TA dan Penambahan $\quad \mathrm{H}_{2} \mathrm{O}_{2} \quad$ Terhadap Elektrodekolorisasi Pewarna Indigo [skripsi]. Universitas Diponegoro Semarang.

Hefnawy, M. A., Gharieb, M. M., Shaaban, M. T. \& Soliman, A. M., 2017. Optimization of Culture Condition for Enhanced Decolorization of Direct blue Dye by Aspergillus flavus and Penicillium canescens. Journal of Applied Pharmaceutical Science, 7(2) : 83-92,

Herfiani, Z. H., Rezagama, A., \& Nur, M. 2017. Pengolahan limbah cair zat warna jenis indigosol blue (C.i Vat Blue 4) sebagai hasil produksi kain batik menggunakan metode ozonasi dan aadsorpsi arang aktif batok kelapa terhadap parameter cod dan warna. Jurnal Teknik Lingkungan, 6 (3): 110.

Kunjadia, P. D., Sanghvi, G. V., Kunjadia, A. P., Mukhopadhyay, P. N., \& Dave, G. S., 2016. Role of ligninolytic enzymes of white rot fungi (Pleurotus spp.) grown with azo dyes. Springerplus, 5 : 1487-1495.
Przystas, W., Zabłocka-Godlewska, E., \& Grabinska-Sota, E., 2018. Efficiency of Decolorization of Different Dyes using Fungal Biomass Immobilized on Different Solid Supports. Brazilian Journal of Microbiology, 49(2) : 285-295.

Rahmat, N. A., Ali, A. A., Salmiati., Hussain, N., Muhammad, M. S., Kristanti, R. A., \& Hadibarata, T., $2016 . \quad$ Removal of Remazol Brilliant Blue $\mathrm{R}$ from Aqueous Solution by Adsorption Using Pineapple Keaf Powder and Lime Peel Powder. Water, Air, and Soil Pollution, 227(195) :. $1-11$.

Singh, A., Ghosh, A., \& Dastidar, M. G., 2018. Decolorization of Reactive Yellow 17 Dye Using Aspergillus tamarii. Environmental Pollution, 77 : 309-316.

Steingruber, E. 2004. Indigo and Indigo Colorants. Ullmann's Encyclopedia of Industrial Chemistry, Wiley-VCH, Weinheim.

Torgut, G., Tanyol, M., Biryan, F., Pihtili, G., \& Demirelli, K., 2017. Application of response surface methodology for optimization of Remazol Brilliant Blue R removal onto a novel polymeric adsorbent. Journal of Taiwan Institute of Chemical Engineers, $80: 406-414$

Yucel, T. T., 2018. Investigation of Some Parameters Affecting Methyl Orange Removal by Fusarium acuminatum. Brazilian Archives of Biology and Technology, 61 : 1-9.

Zhang, F. \& Yu, J., 2000. Decolorization of Acid Violet 7 With Complex Pellets of White Rot Fungus and ActivatedCarbon. Bioprocess Engineering, 23(3) : 295-301 